\title{
AGRI-ENVIRONMENTAL PAYMENTS IN ROMANIA: FARMERS' MOTIVATIONS AND IMPEDIMENTS FOR PARTICIPATION
}

\author{
Meike FIENITZ \\ Technical University Berlin, Faculty VI Planning Building Environment; Freie Universität Berlin, Environmental Policy \\ Research Centre (FFU), GERMANY \\ meike.fienitz@fu-berlin.de \\ DOI: http://doi.org/10.23740/TID120184
}

\section{ABSTRACT}

Agri-environmental payments are a key element of the environmental efforts in the European Union's Common Agricultural Policy. Being a voluntary scheme, they can however only be effective if enough farmers choose to participate. While the factors influencing farmers' decision (not) to participate in agri-environment schemes have been widely studied in the Old Member States, almost no research exists regarding agri-environment scheme uptake in the New Member States. This paper therefore determines which factors motivate farmers in the Târnava Mare region, Romania, to participate in agri-environment schemes, which factors impede the decision to participate, and which lead farmers to quit participation. To do so, the results of 13 case studies of participants, drop-outs, and nonparticipants are analysed and backed with findings from expert interviews. Results are then compared to previous findings from Western Europe, revealing significant differences between the decision-making of farmers in the Târnava Mare region and those examined by previous research. Thus, this paper demonstrates that findings from Old Member States regarding agri-environment scheme uptake cannot simply be assumed to hold for New Member States, a fact that should be considered in EU policy making. This highlights the importance of conducting research in Eastern European countries for schemes to reach their full potential across Europe.

Keywords: payments for eco-system services, CAP, farmers' reasoning, sustainable agriculture, biodiversity

\section{INTRODUCTION}

Agri-environment schemes (AESs) represent one policy instrument which aims to reconcile agricultural production with environmental sustainability. The European Commission defines agri-environmental payments (AEPs) as measures which "provide payments to farmers who subscribe, on a voluntary basis, to environmental commitments related to the preservation of the environment and maintaining the countryside" (European Commission, 2017). They are an important part of the European Union's (EU) attempts to integrate environmental concerns into the Common Agricultural Policy (CAP) and thus to meet society's demand for environmental services. Farmers sign up for a period of at least five years during which they apply environmentally friendly farming techniques which go beyond legal requirements. In return, they are compensated for foregone income and additional costs through a hectare-based fixed price, which differs for each country. First introduced into the European Union's agricultural policy in the late 1980s, AEPs have been compulsory for Member States to apply as part of their rural development plans since 1992 (European Commission, 2017).

With its accession to the EU in 2007, Romania has become part of the CAP and therefore of the EU'S AES. The measures currently available to farmers in Romania are a part of Romania's 
National Rural Development Program (NRDP) and administered by the Romanian Agricultural Payments Agency APIA (Agenţia de Plăţi şi Intervenţie pentru Agricultură). During the first period, around 240,000 Romanian farmers participated, but this number has shrunk by almost a third in the current period (Popa, 2017). Nevertheless, AEPs are the NRDP's most successful program, both in terms of participation and use of budget (Fundația ADEPT (a)).

Romania's most important agri-environmental measure focuses on the protection of hay meadows in high nature value (HNV) areas and is therefore only available to farmers in regions which the Romanian government has defined as HNV, i.e. the Carpathians, the Carpathian foothills, and the hill area. This is the measure analysed in this paper, since it is the biggest one in Romania and the only one available to farmers in the study region. There are, however, also other measures targeting specific species, which are available for example to farmers in the steppe areas (Popa, 2017).

AEPs are usually thought of as focused on environmental risks related to intensive agricultural production, however, in more extensive farming regions, environmental risks are usually linked to the abandonment of labour-intensive traditional farming practices which are crucial to preserving nature (European Commission, 2005, p. 4). This is the case in Romania where the payments for HNV meadows focus on continuing traditional management of hay meadows to preserve a cultural landscape which is extremely rich in biodiversity. Participation in the AES demands that farmers mow hay meadows annually or let animals graze on them so they do not become overgrown by shrubs, but only after June $15^{\text {th }}$ (July $1^{\text {st }}$ in mountainous areas) so that wildflowers can develop seeds. There is also a limit on stocking rates of one livestock unit per hectare and a limit on the use of fertilizers, with artificial fertilizers being entirely banned (Fundația ADEPT (a); Popa, 2017). In 2015, payments for the HNV meadows program were 93 euros per hectare and year. The AES also has a higher tier which grants additional payments of 21 euros/ha/year if farmers use only light machinery, or an additional 100 euros/ha/year if they use no machinery at all and only mow by hand (Dobre, 2016).

Besides this AES administered by APIA, there is a second agri-environmental program available to farmers in the study region. Since 2016, the European Union runs pilot projects in Spain, Ireland, and Romania to test results-based AEPs. In contrast to the existing scheme, in which farmers are paid for conducting certain measures independent of whether these measures actually led to the desired results, i.e. biodiversity protection, results-based schemes provide money for the outcome, without testing if measures have been conducted. In Romania, two pilot projects are conducted in different regions. The one located in the study region is administered by Fundația ADEPT, a non-governmental organization which is active in protecting biodiversity and enhancing rural development. Identical to the APIA administered program, the pilot project aims to protect biodiversity on hay meadows. Payment rates are calculated using the same assumptions as for APIA's program. However, while farmers are advised to conduct the same measures to ensure the preservation of biodiversity, this is not monitored. Instead, ADEPT inspects farmers' fields annually for the presence of certain indicator species. Farmers are then paid according to the number of species present. The same land can only be entered into either APIA's or ADEPT's program, but farmers may participate in both programs at the same time with different parcels (Popa, 2017).

A large body of research exists globally which examines all kinds of aspects related to agrienvironmental payments. Some authors discussed how to set up AEPs in an administratively feasible and economically efficient way - see, for example, Claassen et al. (2008) and Baylis et al. (2008). Other scholars analysed in how far AEPs deliver the environmental services they were supposed to deliver (Prager et al., 2012) and how to evaluate this (Mortimer et al., 2010). 
Since AEPs are voluntary measures, the question of what leads farmers to participate features prominently in the literature. However, virtually no literature on AEP uptake in Romania exists. In fact, the author could not find literature including any of the NMS, with the exception of the Czech Republic, which is covered by two studies (Ducos et al., 2009; Polman \& Slangen, 2008). Instead, most European research focusses on the UK, where AESs have been in use the longest, with most of the additional literature available examining other Western European countries such as Germany, Spain, Italy, and Belgium. This strain of literature mainly attempted to profile participants of AESs and to determine farmer and farm properties which made participation more likely (cf. Lastra-Bravo et al., 2015; Defrancesco et al., 2008; Polman \& Slangen, 2008; Vanslembrouck et al., 2002; Wynn et al., 2001). In particular, the effect of (transaction) costs on participation has been in the focus of many researchers (cf. Falconer 2000; Ducos et al., 2009; Peerlings \& Polman, 2004). Also the influence that farmers' (environmental) attitudes had on the likelihood of participation was frequently analysed (cf. Wilson 1996; Morris \& Potter, 1995).

However, determining farmer and farm properties which make participation likely is of limited interest to policy makers. These properties cannot easily be changed, and we learn little through them about how to improve the effectiveness of agri-environmental schemes. The actual obstacles which make schemes less attractive to farmers with certain characteristics remain unclear. Thus, another strain of research tries to gain an understanding of the motivations of participants and non-participants. For example, in a case study on agri-environmental measures in the UK, Skerrat analyses criteria and factors involved in farmers' decision-making (1998). Also for the UK, Morris et al. provide an analysis of farmers' willingness to participate in one specific agri-environmental measure, the Arable Field Margins option of the UK Countryside Stewardship Scheme (2000). Similarly, Wynne-Jones evaluates farmers' reactions to the Glastir AES in Wales and thus analyses their rationale for participation (2013).

Sattler and Nagel determine scheme-related factors which influence farmers' acceptance of conservation measures in North-Eastern Germany, including agri-environmental payment measures (2010). Venturing in a similar direction, Ruto and Garrod conduct a choice experiment among farmers in Northern Italy to investigate which scheme designs are favoured by farmers and which trade-offs in scheme design farmers are willing to make (2009). Similarly, EspinosaGoded et al. examine the impact of scheme design on participation, by conducting a choice experiment among Spanish farmers (2009).

Van Herzele et al. are the closest to this research project: they use qualitative interviews among farmers in the Dyle Valley, Belgium, to examine farmers' rationale for participation in agrienvironmental measures, although they do not explore reasons why farmers do not participate (2013). In a second step, they test their results in a quantitative analysis of a larger survey among farmers in Belgium. Finally, in order to compare farmers' decision-making across different countries, Wilson and Hart analyse a survey conducted in Austria, Denmark, France, Germany, Greece, Portugal, Spain, Sweden, Switzerland, and the UK complimented by in-depth interviews with some of the farmers surveyed as well as expert interviews to investigate factors motivating farmers (not) to participate in agri-environmental schemes (2000). They find that as AESs differ between Member States, so does farmers' decision-making. Furthermore, they also discover pronounced geographical differences in farmers' motivations, especially between Northern Member States and Mediterranean countries. On the whole, however, Wilson and Hart determine that the major findings of previous studies done on the UK also hold for all of the countries examined by them and conclude that farmers generally seem to be facing the same concerns and trade-offs across (Western) Europe. 
Thus, it becomes clear that while scholars have recognised the importance of gaining insights into the motivations and considerations of participants and non-participants of agri-environmental schemes, and some findings from studies conducted in Western Europe exist, the NMS are tremendously underrepresented when it comes to research regarding farmers' motivations to participate in AEP schemes. However, these countries display very different agricultural, economic, social, and cultural circumstances from the OMS. Romania, for example, has over 3 million agricultural holdings on a utilisable agricultural area (UAA) of 13,306,130 ha, the average area per holding being only 3.4 ha (Eurostat (c)). For comparison: Germany has a slightly larger UAA of $16,704,030$ ha, but less than 300,000 holdings with an average area of almost 60 ha, and in the UK the average area per holding is 84 ha (Eurostat (b) and (d)). Also, in 2014, roughly 10,000 tonnes of pesticides were sold in Romania, while in the UK this number was at 22,663 tonnes and in Germany at more than 46,000 tonnes (Eurostat (a)). Evidently, Romanian farmers operate under very different conditions from those of Western Europe, and assuming that the causal factors involved in their decision-making regarding AES participation are identical would be premature. Nevertheless, CAP's AES is designed for all Member States, but using knowledge collected almost exclusively in the OMS. If this knowledge is not transferrable, the AES runs the risk to underperform in the NMS. Therefore, this paper examines why farmers in Romania choose (not) to participate in agri-environment schemes, and whether they do so for the same reasons that have been found relevant in the existing literature. Because of the striking differences between agriculture in Romania and Western Europe outlined above it is hypothesised that the factors that farmers consider in their decision-making for or against AES participation also differ considerably from those that have been found relevant for the OMS. To test this hypothesis, the following subquestions are examined:

\section{Which factors motivate farmers in Romania to participate in AESs?}

\section{Which factors lead farmers to decide against participation?}

These questions are answered through a comparative analysis of 13 case studies of participants, drop-outs, and non-participants, and backed with findings from expert interviews. Thus, a typology of four pathways to participation and non-participation is created. Results are then compared to findings from the literature. Furthermore, it is also deducted how schemes could be modified to be more successful in attracting applicants and maintaining participants in Romania, and how EU policy making regarding AESs could be improved.

\section{METHODOLOGY}

In-depth semi-structured interviews were conducted with 13 farmers in the Târnava Mare region in Central Romania (Figures 1 and 2). The interviewees were from six different villages: Saschiz (6 cases), Malâncrav (3 cases), Viscri (1 case), Țopa (1 case), Albești (1 case), and Florești (1 case). Two interviewees had never participated in any AES, three had dropped out of APIA's program, two had switched from APIA's to ADEPT's AES, and six still participated in one or both AESs.

These case studies were complimented by three interviews with experts who were responsible for administering the AESs in the same region. Expert interviews were used to determine if findings from individual cases were common across the region. They were selected based on their experience conducting AESs in the Târnava Mare area and their ability to evaluate motivations and impediments in farmers' decision-making.

The interviewed experts were an employee of Fundația ADEPT who is responsible for consulting farmers regarding AEPs and conducting the pilot project in Târnava Mare, an employee of APIA in 
Sighișoara who is responsible for receiving farmer's applications for subsidies, including AEPs, and an employee of the Saschiz mayor's office, who provides farmers with the paper work they need to apply for the agri-environmental payment program at APIA and at Fundația ADEPT. He also assisted farmers with their applications during the first years of the APIA program.

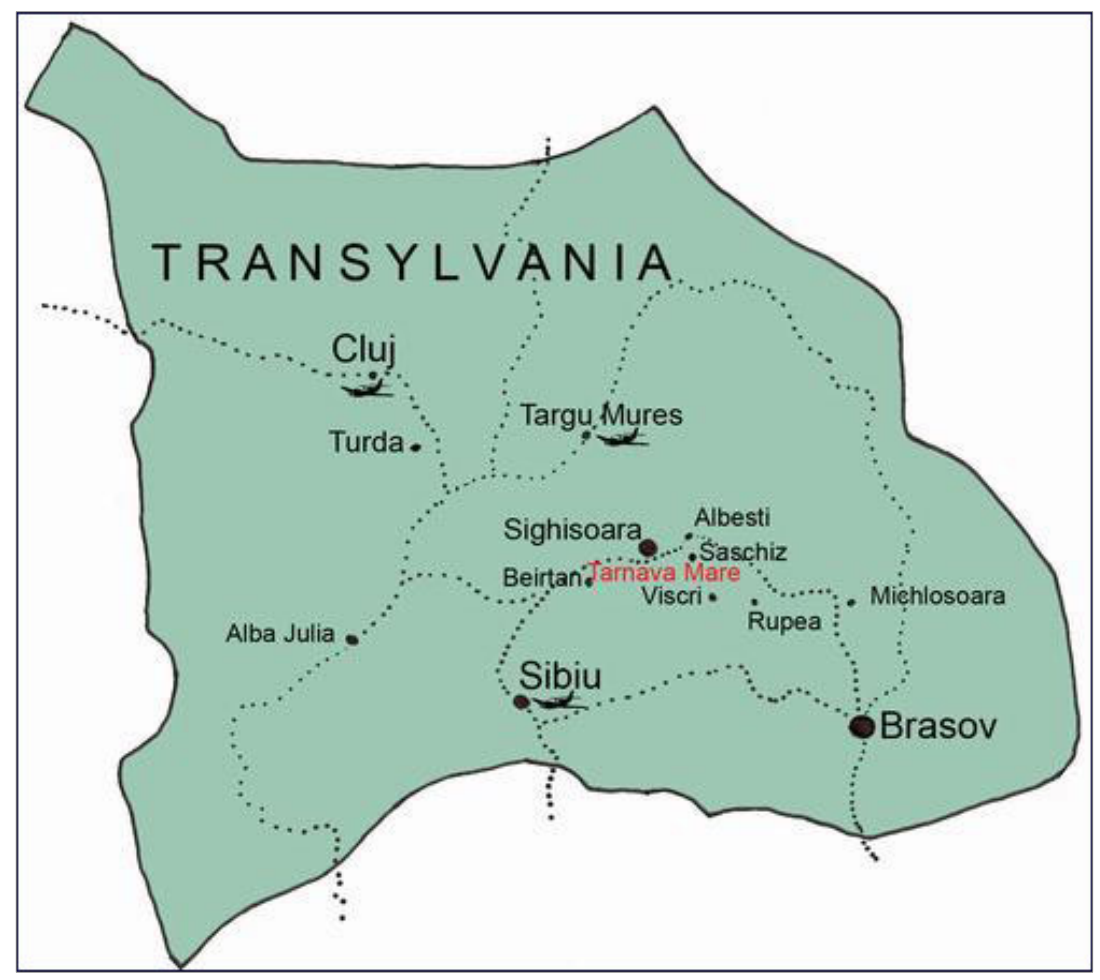

Figure 1: Location of the Târnava Mare region within Transylvania Source: http://www.discovertarnavamare.org/discover/map/

The Târnava Mare area was chosen because it is the region where Fundația ADEPT is particularly active. Through one of their projects, ADEPT has promoted APIA's program to farmers in Târnava Mare (Fundația ADEPT (a)). Furthermore, it is also where ADEPT is conducting the pilot AES. Thus, the Târnava Mare area offered suitable conditions to find farmers who knew about at least one AES (administered by APIA or ADEPT) and had thus been able to make a conscious decision about participation.

A slightly simplified, manual version of the qualitative content analysis as described by Gläser and Laudel (2004) was used to analyse the interviews. In a first preparatory step, a literature review was conducted to identify factors which had been found to influence farmers' decisionmaking for or against participation in AESs in the European Union. Only those factors which had been found by at least two studies to have an influence on (non-)participation were incorporated. In a second step, the resulting list of variables was used for extraction. Each interview was examined chronologically for manifestations of variables. Whenever a factor was found which was not already in the list of variables, a new variable was added.

From this raw data an analysis of the pathway of each individual case was derived. Then, cases were compared in order to create a typology of different routes to participation or nonparticipation and to identify variables which were of particular significance. From this, a comparison to the findings from the expert interviews and, in a second step, to the literature was drawn. 


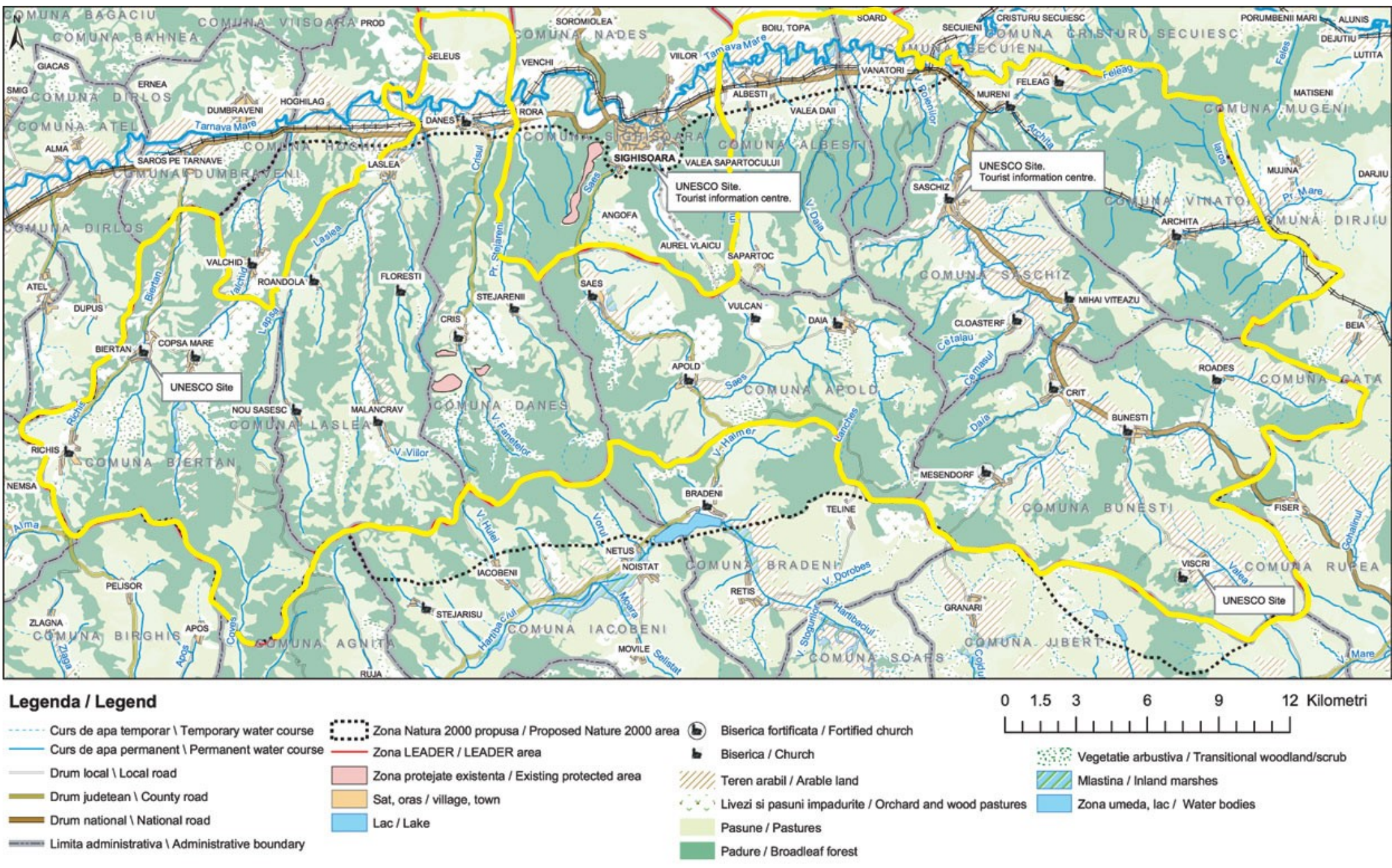

Figure 2: Research area where cases were selected

Source: http://www.discovertarnavamare.org/wp-content/uploads/2011/12/tm-map1-med.jpg 
Reviewing the existing literature on farmers' motivations (not) to participate in AESs resulted in a list of eight variables leading to participation and ten variables impeding participation (see Tables 1 and 2). The most important motivators were financial incentives and a good fit of the demanded agri-environmental measures with existing farming practices (referred to, in this paper, as goodness of fit), which featured prominently in the literature. The influence of neighbours and friends, as well as environmental considerations were also mentioned frequently in the literature, but were found to be of mixed importance: in some studies, they featured strongly, yet in others they were only mentioned by few farmers. A positive previous experience with support programs, a good level of information about the functioning of the scheme, and the presence of a trusted professional advisor were mentioned less frequently, but were also found to impact farmers' decision-making. The effect which participation had on a farm's image, in turn, was mentioned in only two of the studies as a motivator and was only of medium to low importance even there. Thus, it can be seen as the weakest positive variable in the theoretical framework.

As for the negative variables which farmers named as impediments to participation, the picture is more divided. Lack of information, bureaucracy, being unconvinced about the effectiveness of the scheme or disagreeing with its aims, the opinion of neighbours and friends, and the perception that the money paid was insufficient were all frequently found to play into farmers' decision against participation by a number of studies, but none of them could be made out as a major factor. Additionally, a sense of loss of autonomy due to participation, the feeling that the contract period was too long, mistrust in government, and a bad fit of the measures with existing farm management were identified as further considerations in farmers' decision-making which led to non-participation, but were mentioned less frequently in the literature.

Table 1: Motivations to Participate

\begin{tabular}{|c|c|c|c|}
\hline$\overline{\text { Variable }}$ & Literature & Variable & Literature \\
\hline $\begin{array}{l}\text { Financial } \\
\text { incentives }\end{array}$ & $\begin{array}{l}\text { - Skerrat (1989) } \\
\text { - Morris and Potter (1995) } \\
\text { - Morris et al. (2000) } \\
\text { - Sattler \& Nagel (2010) } \\
\text { - Van Herzele et al. (2013) } \\
\text { - Wilson \& Hart (2000) } \\
\text { - Wilson (1996) } \\
\text { - Wynne-Jones (2013) } \\
\text { - Espinosa-Goded et al. (2010) }\end{array}$ & $\begin{array}{l}\text { Goodness } \\
\text { of fit }\end{array}$ & $\begin{array}{l}\text { - Morris \& Potter (1995) } \\
\text { - Skerrat (1989) } \\
\text { - Lastra-Bravo et al. (2015) } \\
\text { - Morris et al. (2000) } \\
\text { - Defrancesco et al. (2008) } \\
\text { - Van Herzele et al. (2013) } \\
\text { - Wilson \& Hart (2000) } \\
\text { - Wilson (1996) } \\
\text { - Wynn et al. (2001) } \\
\end{array}$ \\
\hline $\begin{array}{l}\text { Environmental } \\
\text { reasons }\end{array}$ & $\begin{array}{l}\text { - Skerrat (1989) } \\
\text { - Morris et al. (2000) } \\
\text { - Van Herzele et al. (2013) } \\
\text { - Wilson \& Hart (2000) } \\
\text { - Wilson (1996) }\end{array}$ & $\begin{array}{l}\text { Positive } \\
\text { experience with } \\
\text { support } \\
\text { programs }\end{array}$ & $\begin{array}{l}\text { - Lastra-Bravo et al. (2015) } \\
\text { - Skerrat (1989) } \\
\text { - Wilson \& Hart (2000) } \\
\text { - Espinosa-Goded et al. (2010) }\end{array}$ \\
\hline $\begin{array}{l}\text { Neighbours and } \\
\text { friends }\end{array}$ & $\begin{array}{l}\text { - Skerrat (1989) } \\
\text { - Lastra-Bravo et al. (2015) } \\
\text { - Wilson \& Hart (2000) } \\
\text { - Van Herzele et al. (2013) } \\
\text { - Morris et al. (2000) }\end{array}$ & Trusted advisor & $\begin{array}{l}\text { - Skerrat (1989) } \\
\text { - Wilson \& Hart (2000) } \\
\text { - Lastra-Bravo et al. (2015) } \\
\text { - Espinosa-Goded et al. (2010) }\end{array}$ \\
\hline Image & $\begin{array}{l}\text { - Wilson \& Hart (2000) } \\
\text { - Van Herzele et al. (2013) }\end{array}$ & & \\
\hline
\end{tabular}


Table 2: Impediments to Participation

\begin{tabular}{|c|c|c|c|}
\hline$\overline{\text { Variable }}$ & Literature & Variable & Literature \\
\hline $\begin{array}{l}\text { Lack of } \\
\text { Information }\end{array}$ & $\begin{array}{l}\text { - Wilson \& Hart (2000) } \\
\text { - Lastra-Bravo et al. (2015) } \\
\text { - Morris et al. (2000) }\end{array}$ & $\begin{array}{l}\text { Unconvinced } \\
\text { about } \\
\text { effectiveness }\end{array}$ & $\begin{array}{l}\text { - Morris \& Potter (1995) } \\
\text { - Falconer (2000) } \\
\text { - Sattler \& Nagel (2010) } \\
\text { - Wilson \& Hart (2000) }\end{array}$ \\
\hline Bureaucracy & $\begin{array}{l}\text { - Skerrat (1989) } \\
\text { - Falconer (2000) } \\
\text { - Ruto \& Garrod (2009) } \\
\text { - Wilson \& Hart (2000) }\end{array}$ & $\begin{array}{l}\text { Money is } \\
\text { insufficient }\end{array}$ & $\begin{array}{l}\text { - Skerrat (1989) } \\
\text { - Morris \& Potter (1995) } \\
\text { - Wilson \& Hart (2000) }\end{array}$ \\
\hline $\begin{array}{l}\text { Sense of } \\
\text { autonomy loss }\end{array}$ & $\begin{array}{l}\text { - Skerrat (1989) } \\
\text { - Morris \& Potter (1995) } \\
\text { - Morris et al. (2000) }\end{array}$ & $\begin{array}{l}\text { Neighbours and } \\
\text { friends }\end{array}$ & $\begin{array}{l}\text { - Skerrat (1989) } \\
\text { - Defrancesco et al. (2008) } \\
\text { - Wilson \& Hart (2000) } \\
\text { - Falconer (2000) }\end{array}$ \\
\hline $\begin{array}{l}\text { Length of } \\
\text { contract }\end{array}$ & $\begin{array}{l}\text { - Ruto \& Garrod (2009) } \\
\text { - Espinosa-Goded et al. (2010) }\end{array}$ & $\begin{array}{l}\text { Mistrust in } \\
\text { government }\end{array}$ & $\begin{array}{l}\text { - Ducos et al. (2009) } \\
\text { - Lastra-Bravo et al. (2015) }\end{array}$ \\
\hline $\begin{array}{l}\text { Disagree with } \\
\text { aims of scheme }\end{array}$ & $\begin{array}{l}\text { - Morris and Potter (1995) } \\
\text { - Morris et al. (2000) } \\
\text { - Wynne-Jones (2013) }\end{array}$ & Bad fit & $\begin{array}{l}\text { - Wilson and Hart (2000) } \\
\text { - Espinosa-Goded et al. (2010) } \\
\text { - Morris et al. (2000) }\end{array}$ \\
\hline
\end{tabular}

Thus, if findings could be transferred from the existing studies to Romania, we would expect most of these variables to be mentioned by Romanian farmers as well, with financial incentives and goodness of fit serving as particularly important motivators.

\section{RESULTS AND DISCUSSION}

Through comparison of the farmers' individual pathways to (non-)participation, a typology was created. Thus, four types emerged with distinct pathways:

- Successful and well-informed participants;

- Participants who are influenced by third parties;

- Uninformed drop-outs;

- Anxious drop-outs.

No type emerged from the two non-participants interviewed.

\section{Group 1: Successful and well-informed participants}

\section{Cases $\mathrm{A}, \mathrm{B}, \mathrm{N}$, and $\mathrm{K}$}

While each farmer is different and has his or her own reasoning, there are some common characteristics among these cases which suggest that they can be classified as one type. First of all, all of these farmers were relatively well-informed. While $A$ and $N$ are both politically active, $\mathrm{K}$ emphasised that he read the fine print before signing for APIA's AES. None of the farmers in group 1 complained about a lack of information with the exception of $A$, but this only referred to the beginning of his participation, before he read more about the program.

No one in this group ever had to pay money back, which means they most likely respected the measures. This makes sense regarding the good level of information in this group. Obviously, a 
farmer who understands what the program is about and what he or she has to do to comply will be able to participate successfully.

All farmers in this group also mentioned environmental reasons as a more or less important motivation to participate, and a certain level of environmental awareness seems to have been present in all of them even before starting participation. This may also be a reason for their successful and continued participation: a farmer who not only participates for the money, but supports the environmental aims of AESs, will conduct the measures more carefully and will want to continue participation in the future, even in the face of obstacles such as bureaucracy. This point is confirmed by the results of the other cases since no participant who named environmental reasons as a motivation ever had to pay money back or quit participation in AESs.

Most of the farmers in this group also emphasised the importance of goodness of fit, in fact, for $\mathrm{A}, \mathrm{B}$, and $\mathrm{K}$ it was a major motivator. $\mathrm{N}$ did not explicitly mention goodness of fit, but did so indirectly by stating that he could not see any disadvantages in participating in ADEPT's program, which must mean that he also did not have to change much in his farming practices. Likely, the good fit also helped these farmers to participate as successfully as they did.

While farmers in group 1 did see some negatives about participation, such as bureaucracy, unreliability, or disagreeing with the means of the scheme, these never entirely kept them from participating. At most, potential impediments caused them to switch to ADEPT's scheme or to skip a year and reduce the number of parcels in the program.

Thus, group 1 farmers are the ideal participants which any scheme aims for: they understand the program, its measures and aims, they are motivated by the money but also support the environmental goals. These two variables combined create enough of an incentive that farmers tend to continue participation even when faced with impediments. Nevertheless, it is possible that these farmers would drop out of AESs if the hurdles to participation were bigger and goodness of fit was not given anymore. This is shown by case $K$, who switched to ADEPT when he heard that APIA's program was supposed to become increasingly difficult to comply with, and by $B$, who decided against participation in the higher tier, because this would have meant some adaptation of his current farm management. Thus, the programs do not seem to be able to motivate these farmers to significantly alter farming practices. More of an incentive - for example, higher payments - appears to be necessary for that.

\section{Group 2: Participants Who Are Influenced by Third Parties}

\section{Cases D, E, F, and G}

Farmers in group 2 were not as strikingly well-informed as those in group 1, and some of them even complained about a lack of information. Also, these farmers seem to have been less aware about environmental issues before taking up participation, although two of them developed conservationist attitudes through participation. Farmers in this group have been strongly influenced by other people: all name either trusted advisors or friends and neighbours as involved in their decision or participation. Goodness of fit again played a role, with farmers $E, F$, and $G$ stating that they could not see any negative aspects about participation - which likely includes that they had to make only minor adjustments in farming practices - while D directly referred to goodness of fit. All farmers in this group evaluate AESs as very positive; they see many advantages in participation and very few disadvantages.

However, there may be some risks to these farmers' continued successful participation. One of them admitted that he did not understand the measures very well and only did whatever he was 
told to. Thus, he depends on advisors and helpful staff for being able to comply. In this respect, he is very similar to some of the drop-outs in group 3. Given the overall lower levels of information in this group, it is also possible that some of these farmers in fact do not conduct all the measures correctly and have simply not been inspected yet. If this was the case, they might run risk to fall into group 3 in the future.

\section{Group 3: Uninformed Drop-outs}

Cases $\mathrm{H}, \mathrm{C}$, and $\mathrm{E}$

Also among the drop-outs, two different types emerged. For farmers in group 3, the root cause for quitting participation was lack of information: They did not understand APIA's program well, filled in forms incorrectly, and possibly did not conduct the measures properly. Thus, they had to pay back money, yet often did not even understand why: one of the farmers believed that the program must have ceased to exist. Finally, all of the farmers in this group were so frustrated that they decided to drop out and would never participate in the program again. Thus, lack of information seems to stand at the beginning of a typical pathway towards dropping out of AESs, even though it tends to work indirectly through not understanding the measures, failing inspections, having to pay back money, and then dropping out. This finding was also confirmed by one of the experts.

\section{Group 4: Anxious Drop-outs}

\section{Cases $\mathrm{L}$ and $\mathrm{K}$}

The most important factor in the other pathway to dropping out was fear of inability to comply. $\mathrm{K}$ dropped out of APIA's scheme because APIA staff told him that it would be increasingly difficult to participate. This can be classified as fear of inability to comply, because apparently APIA's warnings worried $\mathrm{K}$. This fear was complimented by a sense of discontent with the effectiveness of the program on a national scale and some general disagreement with these types of subsidies. Also L's main reason to give up participation was inability to comply, however, in her case this fear was caused by an experience of vandalism, which combined with the feeling that the money paid was too little for the amount of administrative work. Thus, fear to be unable to comply was the main driver for dropping out in both cases, although the cause of the fear differed among them.

\section{Non-participants}

\section{Cases $\mathrm{M}$ and $\mathrm{J}$}

Decision-making was very different between the two non-participants, and no typology could be created. For $M$, the main reason against participation was that she had found farming to be not worthwhile financially and had found a much more lucrative employment abroad. In contrast, the most important impediment for J was that his family had had a negative previous experience with participation in APIA's AES (they had dropped out), and this made him unwilling to invest time and energy into gathering information even about ADEPT's program. Thus, a negative experience can be passed down into the next generation and make farmers unwilling to consider participation even in other AESs. This emphasises the importance of tackling the causes for dropping out which were described in groups 3 and 4. 


\section{Additional Findings}

Apart from this typology, additional interesting findings emerged from comparing all cases (see also Tables 3 and 4). Most strikingly, for virtually all farmers interviewed, the financial aspects were initially a positive factor in their considerations to participate. Thus, the money paid is a main motivator which made all farmers at least consider participation. This was also emphasised by all three experts, highlighting the general validity of this finding. Since farming in Romania is a financially highly risky endeavour, this comes at little surprise. Only three farmers - two dropouts and one non-participant - concluded after trading off that the money was insufficient for the efforts that had to be undertaken. Interestingly, even one non-participant and several dropouts found AEPs financially attractive. Therefore, recognising that the program is financially attractive is common, but not a sufficient condition for participation. Instead, other factors have to explain variation in participation.

Goodness of fit could be such a variable: All farmers who named goodness of fit as a factor in their decision-making still participate. This is logical: if participation requires no or only minor changes, it will be easy to comply with the measures, and even if the sum paid is little, it will likely trade-off as a net plus. Thus, farmers whose farm management fit AESs well anyway will likely participate successfully. In fact, all farmers who still participate named either goodness of fit or no trade-off, which - as explained above - must also include goodness of fit. In turn, of those who permanently quit or never participated, none named either goodness of fit or no trade-off. Thus, within the cases examined, goodness of fit and no trade-off were functional equivalents which together operated as sufficient variables for participation, and might even be a necessary condition. However, this finding should not be over-rated: there could have been a tendency among farmers to explain their decision, more than to name reasons that would have stood against it. Thus, if goodness of fit was given, a farmer who decided against participation may not have named it in the interview, while a farmer who wanted to explain why he or she participated was more likely to include goodness of fit in their list of reasons. Even with some caution, though, this suggests that goodness of fit is an important contributor to both the decision to participate and successful participation, a finding again confirmed by the experts.

The same is true for environmental reasons: No farmer who mentioned environmental reasons dropped out of AESs permanently, only K switched programs. Among the cases examined in this study, environmental motivations were therefore a sufficient condition for successful participation. This makes sense, as farmers who are not motivated by financial aspects alone will be more likely to put up with potential impediments, will conduct measures more carefully, will be motivated to learn new techniques through the program, and will consider participation in alternative programs if they do decide to drop out (such as $\mathrm{K} \mathrm{did).}$

A positive previous experience with AESs or similar programs always led to participation. In contrast, a negative previous experience always led to non-participation and in case J was the main reason for it. The importance of previous experiences was furthermore confirmed by the experts. Thus, previous experiences are an important determinant of future decisions.

A trusted advisor was a motivator for several of the farmers interviewed, and, as mentioned above, played a particularly important role in the decision-making of farmers in group 2. None of the farmers who participated because of an advisor ever dropped out, which suggests that advisors do their job well. The only case where a trusted advisor was mentioned but did not lead to participation was J, however, he was very reluctant to participate because of his family's previous negative experience and the perceived bureaucracy of the program. 
Influence of neighbours can lead to successful or unsuccessful participation. In both cases which named neighbours as a reason for their decision to participate, this led to participation. However, case E participated in APIA's program because he saw all his neighbours doing the same, but then was insufficiently informed about what he needed to do, had to pay money back and eventually quit. In contrast, in case $D$, a neighbour and good friend put D's name on the list for participation in ADEPT's program, D found ADEPT staff to be very helpful and so far participates without problems. The more wide-spread importance of the influence of neighbours was confirmed by the experts. Thus, neighbours can be important to trigger the initial decision to participate, but the longer-term success of participation is determined by other factors, such as in these cases lack of information vs. the presence of trusted advisors.

Interestingly, not a single farmer named the effect on the farm's image as a consideration, nor was this point raised by any of the experts. Hence, it can be concluded that the farm's image does not play an important role in the decision-making among farmers in the Târnava Mare area.

In turn, several variables had to be added to those in the theoretical framework. For positive variables which led to participation these were reliability, no bureaucracy, no trade-off, recognition of own work, program is effective, and program helps to raise environmental awareness. None of these variables were mentioned by any of the experts, and most of them were only mentioned by single farmers. Furthermore, besides no trade-off, which was a main argument for participation for three of the farmers in group 2, none of the added variables were mentioned by the farmers as of particular importance to their decision. Therefore, further research is necessary to test if these variables are of more than marginal significance.

Among the negative variables, the picture is more mixed: the list of negative variables mentioned by farmers is much longer, but many were only named by one or two interviewees, suggesting that reasons against participation vary more between farmers. Nevertheless, comparison of all cases resulted in several interesting findings.

For one, lack of information lead to non-participation or dropping out, except in case A, who managed to become better informed during participation, and in case $F$, who relies on assistance by APIA staff to do everything correctly. It was also mentioned as an impediment by every single non-participant or drop-out in this study, except K. Lack of information also is a common obstacle across the Târnava Mare region, as was confirmed by the experts. Finally, it also was the main cause in one of the two pathways to dropping out that were discovered. Therefore, lack of information clearly is a major impediment in the Târnava Mare area.

Similarly, perceiving bureaucracy as problematic always led to non-participation or dropping out, except in cases A and N. In both of them bureaucracy was a problem, but not so big as to cause them to quit. Positive aspects (such as goodness of fit and environmental reasons) outweighed it. The farmers for whom bureaucracy did lead to non-participation or AES abandonment also named much more other negative aspects than these two cases. To them, AEPs were too bureaucratic for the little advantages they saw in them. Thus, bureaucracy can be outweighed by other considerations, but if too little positives are perceived and too many negatives, it turns into an important argument against participation: for three of the nonparticipants, it was one of their main reasons. The significance of this finding was confirmed by the experts, who also saw bureaucracy as an impediment across the Târnava Mare region.

Fear to be unable to comply was another major impediment: It was found to be the main driver in one of the pathways to dropping out. Moreover, the only case when it did not lead to nonparticipation was $B$ (and in all other cases, it played a very important role in the decision against participation). For $B$, it led to skipping one year of participation, but then he re-joined, although 
with less surfaces. B does not state why he decided to re-join, but since he was able to switch to ADEPT with most of his parcels, he may have perceived it as less of a risk when he entered only one parcel into APIA's program, or he may have gained more information convincing him that he would be able to comply after all. Thus, some uncertainty remains as to what can trump fear of inability to comply. Also, this variable was not mentioned by any of the experts, leaving its quantitative relevance to be tested in the future.

Experiencing the program as unreliable led to non-participation, except in cases A and G. Both farmers name unreliability as a problem that bothers them, but overall they are very happy with the program. They see important advantages in participation and these outweigh the disadvantages. Interestingly, these are both cases which named environmental reasons as a major motivation and who both emphasised goodness of fit or no trade-off. Thus, one or both of these variables may trump unreliability. Nevertheless, unreliability was again not mentioned by the experts and thus needs to be tested further for its frequency.

Matching the importance found for goodness of fit, bad fit always led to non-participation, and the experts confirmed that bad fit was a common impediment. This could be a sign that the money paid is too little: it only motivates farmers to do what can be done easily; once more efforts are needed they are not interested. This is further backed by the finding that the money paid being insufficient was a major reason for dropping out in case $L$, a minor one in case $E$, and a reason against participation in case $M$. One of the experts furthermore confirmed that the money being too little is a common impediment across the Târnava Mare area.

Findings regarding the impact of perceived complexity were mixed: While it was a main reason for dropping out in case $\mathrm{C}$, it was a minor one in case $\mathrm{K}$, yet also mentioned by a farmer who still participates. It was not mentioned as an impediment by any of the experts. Thus, more research into the relevance and effect of this variable is needed before conclusions can be drawn.

Disagreement with the aims or means of the scheme never led to non-participation, only once to switching the program. It was also not mentioned by any of the experts and can therefore be discarded as a major reason to explain non-participation in the Târnava Mare region.

Both, mistrust in government and problems with land registry, were mentioned by two farmers, one who dropped out and one non-participant, but by none of them as a major factor. However, both variables were emphasised by one of the experts and may thus be more significant than they appeared among the cases examined.

Similarly, the length of the contract was only criticised by farmer $A$ and did not have any impact on his decision, but was named as an important impediment by two of the experts. Thus, it may be a significant obstacle in the Târnava Mare region, but the data collected in this project is insufficient to analyse it further.

The ownership situation was not named as an impediment to AES participation by the farmers, but by two of the experts. It did however appear indirectly in M's case, whose leasers are unable to participate in AESs since they cannot legally lease from her because M lacks the inheritance papers for her land. The fact that the ownership situation was not named more often as an impediment may be caused by a case selection bias: when looking for potential interviewees, we asked for those who are technically eligible. Possibly, neighbours did then not name those with insecure contracts. Despite the fact that it was not mentioned explicitly by any of the farmers interviewed, the ownership situation may therefore be a rather common obstacle, as was suggested by the experts. In turn, loss of autonomy and neighbours and friends were not 
named at all as impediments to participation. Since none of the experts mentioned these variables either, they seem to play no significant role in the study region.

Within the impediments, measures are not effective, administrative staff, program is perceived as unfair, and APIA advises against participation were variables of minor importance among the cases examined and not mentioned by the experts. It would be interesting to test this in future research, but for the moment they can be assumed to be indeed not very important in the Târnava Mare area.

Table 3: Manifestations of Motivations for Participation

Green: participants (group 1); blue: participants (group 2); red: drop-outs (groups 3 and 4); yellow: non-participants; highlighted red: APIA drop-outs who switched to ADEPT

Bold: main considerations; ADEPT: for ADEPT program only; () = not stated explicitly

\begin{tabular}{|c|c|c|c|c|c|}
\hline Case & Money & Goodness of fit & $\begin{array}{l}\text { Neighbours } \\
\text { and friends }\end{array}$ & $\begin{array}{l}\text { Environmental } \\
\text { reasons }\end{array}$ & $\begin{array}{l}\text { Positive previous } \\
\text { experience }\end{array}$ \\
\hline A & $(X)$ & $x$ & & $\mathrm{X}$ & \\
\hline B & $\mathbf{x}$ & $x$ & & $x$ & \\
\hline $\mathbf{N}$ & $x$ & & & $x$ & \\
\hline$\kappa$ & $x$ & $x$ & & $x$ & ADEPT \\
\hline D & ADEPT & ADEPT & ADEPT & & ADEPT \\
\hline E & ADEPT & & $x$ & & \\
\hline $\mathbf{F}$ & $\mathbf{x}$ & & & $\mathrm{x}$ & \\
\hline G & (X) & & & $x$ & \\
\hline C & $(\mathrm{X})$ & & & & \\
\hline $\mathrm{H}$ & $x$ & & & & \\
\hline $\mathbf{L}$ & $x$ & & & & \\
\hline$M$ & $x$ & & & & \\
\hline J & $\mathrm{x}$ & & & & \\
\hline
\end{tabular}

\begin{tabular}{|c|c|c|c|c|c|}
\hline Case & Trusted advisor & Effect on farm's image & Information & Reliability & No bureaucracy \\
\hline A & & & $\mathrm{x}$ & & \\
\hline B & & & $\mathrm{X}$ & & \\
\hline $\mathbf{N}$ & & & & & ADEPT \\
\hline K & ADEPT & & & & \\
\hline D & ADEPT & & & ADEPT & ADEPT \\
\hline E & & & ADEPT & & \\
\hline $\mathbf{F}$ & $\mathrm{X}$ & & & & \\
\hline G & $\mathbf{x}$ & & & & \\
\hline C & & & (X) & & \\
\hline H & & & & & \\
\hline $\mathbf{L}$ & & & $(\mathrm{X})$ & & \\
\hline $\mathbf{M}$ & & & & & \\
\hline J & $\mathbf{x}$ & & & & \\
\hline
\end{tabular}


Agri-Environmental Payments in Romania: Farmers' Motivations and Impediments for Participation

\begin{tabular}{|c|c|c|c|c|}
\hline Case & No trade-off & $\begin{array}{c}\text { Recognition of own } \\
\text { work }\end{array}$ & $\begin{array}{l}\text { Measures are } \\
\text { effective }\end{array}$ & $\begin{array}{c}\text { Raise environmental } \\
\text { awareness }\end{array}$ \\
\hline A & & & & $x$ \\
\hline \multicolumn{5}{|l|}{ B } \\
\hline $\mathrm{N}$ & $x$ & & & \\
\hline K & & & ADEPT & \\
\hline \multicolumn{5}{|l|}{$\mathrm{D}$} \\
\hline $\bar{E}$ & ADEPT & & & \\
\hline $\mathbf{F}$ & $x$ & & & \\
\hline G & $x$ & $x$ & & \\
\hline \multicolumn{5}{|l|}{ C } \\
\hline \multicolumn{5}{|l|}{$\mathrm{H}$} \\
\hline \multicolumn{5}{|l|}{$\mathbf{L}$} \\
\hline \multicolumn{5}{|l|}{$M$} \\
\hline J & & & & \\
\hline
\end{tabular}

Table 4: Manifestations of Impediments to Participation

Green: participants (group 1); blue: participants (group 2); red: drop-outs (groups 3 and 4); yellow: non-participants; highlighted red: APIA drop-outs who switched to ADEPT Bold: main considerations; APIA: for APIA program only; () = not stated explicitly

\begin{tabular}{|c|c|c|c|c|c|}
\hline Case & $\begin{array}{c}\text { Lack of } \\
\text { information }\end{array}$ & Bureaucracy & $\begin{array}{c}\text { Loss of } \\
\text { autonomy }\end{array}$ & Contract length & $\begin{array}{c}\text { Disagreement with } \\
\text { aims of scheme }\end{array}$ \\
\hline A & X & X & & X & \\
\hline B & & & & & X \\
\hline N & & X & & & APIA \\
\hline K & & & & & X \\
\hline D & & & & & \\
\hline E & APIA & & & & \\
\hline F & X & & & & \\
\hline G & & & & & \\
\hline C & X & X & & & \\
\hline H & X & X & & & \\
\hline L & X & X & & & \\
\hline M & X & X & & & \\
\hline J & X & X & & & \\
\hline
\end{tabular}

\begin{tabular}{|c|c|c|c|c|c|}
\hline Case & $\begin{array}{c}\text { Measures are } \\
\text { not effective }\end{array}$ & $\begin{array}{c}\text { Money is } \\
\text { insufficient }\end{array}$ & $\begin{array}{c}\text { Neighbours and } \\
\text { friends }\end{array}$ & $\begin{array}{c}\text { Mistrust } \\
\text { government }\end{array}$ & Bad fit \\
\hline A & & & & & \\
\hline B & & & & & X \\
\hline N & & & & & \\
\hline K & APIA & & & & \\
\hline D & & & & & \\
\hline
\end{tabular}


Agri-Environmental Payments in Romania: Farmers' Motivations and Impediments for Participation

\begin{tabular}{|c|c|c|c|c|c|}
\hline E & & APIA & & & \\
\hline F & & & & & \\
\hline G & & & & & \\
\hline C & & & & & X \\
\hline H & & & & & \\
\hline L & & X & & & \\
\hline M & & X & & X & \\
\hline J & & & & & \\
\hline
\end{tabular}

\begin{tabular}{|c|c|c|c|c|c|}
\hline Case & Complexity & $\begin{array}{l}\text { Inability to } \\
\text { comply }\end{array}$ & $\begin{array}{l}\text { Administrative } \\
\text { staff }\end{array}$ & $\begin{array}{l}\text { Negative previous } \\
\text { experience }\end{array}$ & $\begin{array}{l}\text { Program is } \\
\text { unreliable }\end{array}$ \\
\hline A & & & & & $x$ \\
\hline B & & $x$ & & & \\
\hline \multicolumn{6}{|l|}{$\mathbf{N}$} \\
\hline $\bar{K}$ & $x$ & & & & \\
\hline \multicolumn{6}{|l|}{ D } \\
\hline E & & APIA & & APIA & \\
\hline $\mathbf{F}$ & $x$ & & & & \\
\hline G & & & & & $x$ \\
\hline $\mathrm{C}$ & $x$ & $x$ & $x$ & & \\
\hline $\mathrm{H}$ & & & & $x$ & $x$ \\
\hline$L$ & & $x$ & & & $x$ \\
\hline$M$ & & $x$ & & & $x$ \\
\hline $\mathrm{J}$ & & & & $x$ & \\
\hline
\end{tabular}

\begin{tabular}{|c|c|c|c|c|c|}
\hline Case & $\begin{array}{l}\text { Program is } \\
\text { perceived as unfair }\end{array}$ & $\begin{array}{l}\text { APIA advises against } \\
\text { participation }\end{array}$ & $\begin{array}{l}\text { Land } \\
\text { registry }\end{array}$ & $\begin{array}{l}\text { Farming not } \\
\text { worthwhile }\end{array}$ & $\begin{array}{l}\text { Ownership } \\
\text { problems }\end{array}$ \\
\hline \multicolumn{6}{|l|}{ A } \\
\hline \multicolumn{6}{|l|}{ B } \\
\hline $\mathbf{N}$ & $x$ & & & & \\
\hline K & & APIA & & & \\
\hline \multicolumn{6}{|l|}{ D } \\
\hline \multicolumn{6}{|l|}{$E$} \\
\hline \multicolumn{6}{|l|}{$F$} \\
\hline \multicolumn{6}{|l|}{$\mathbf{G}$} \\
\hline \multicolumn{6}{|l|}{ C } \\
\hline \multicolumn{6}{|l|}{$\mathrm{H}$} \\
\hline $\mathbf{L}$ & & & $x$ & & \\
\hline$M$ & & & $x$ & $x$ & \\
\hline $\mathrm{J}$ & & & & & \\
\hline
\end{tabular}


Thus, the sub-questions posed in the beginning can be answered as follows: Major factors that motivate farmers in the Târnava Mare region to participate in AESs are financial considerations, goodness of fit, and environmental considerations, with positive previous experiences, trusted advisors, and neighbours/friends being additional important reasons for some of the farmers. The most important impediments to successful participation are lack of information, bureaucracy, fear to be unable to comply, and negative previous experiences. Unreliability, bad fit, and the money paid being insufficient were further significant obstacles. Overall, the range of negative factors named was much wider than that of positive factors, suggesting that reasons against participation are more diverse.

\section{Comparison to Findings from Existing Literature}

Comparing these results to the findings from the literature analysis, several similarities between the decision-making of farmers in Romania and of those examined by previous research can be detected. Financial incentives and goodness of fit are the two most important motivations among farmers all over Europe. Not only are they mentioned frequently as important variables in the existing literature, but they were also found to be the two factors valid across Western Europe in Wilson and Hart's cross-country comparative study (2000), and could now be confirmed to be valid in Romania as well. Also all of the other main motivators that were found by this study had been mentioned in the literature. Likewise, lack of information and bureaucracy were major impediments both in this project and in the existing literature. Feeling that the money paid was insufficient was also found to be rather important not only in this project, but in the literature as well. Contract length, mistrust in government, and bad fit were mentioned, but less frequently, in the literature and also were of subordinate importance in Târnava Mare Region, with the exception of bad fit, which was a major factor.

However, also a number of striking differences arose. The effect that participation has on a farm's image did not appear as a consideration at all, yet it had been found to be a motivator for participation among farmers in Western Europe, although not a very strong one. This may be because farming in Romania is not as industrialised and has not been criticised as much for causing environmental problems yet. Thus, there may be less of a need for farmers to improve their image.

Likewise, loss of autonomy as well as neighbours/friends did not appear at all as negative factors in farmers' decision-making in this study, yet they had been found to have considerable influence in the existing literature. Why neighbours and friends were not mentioned as important for the decision against participation remains rather unclear, especially since they were important for the decision of those who participated. At any rate, this finding should not be over-interpreted. After all, since this study did not work quantitatively, the fact that none of the farmers mentioned a variable means little if not supported by the experts, and one of the experts did emphasise the importance of friends and neighbours for participation. While he did not explicitly say so, it is possible that he meant this for non-participation as well. For loss of autonomy, on the other hand, it seems likely that this can be explained with the different economic situation of farmers: as several of the Romanian farmers stressed, any additional money is much needed, likely even more so than among farmers in the richer (Western) European countries. Therefore, farmers in the Târnava Mare region may not be able to consider "luxury" arguments such as the loss of autonomy.

Similarly, being unconvinced about the effectiveness of the scheme and disagreeing with its aims were found frequently in the literature, but among the farmers interviewed in this study they 
were of marginal importance in the case of effectiveness and did not lead to dropping out or non-participation in the case of disagreeing with the aims. Again, this could be explained with the different economic situation of farmers. Being able to consider ideological factors is another luxury which many Romanian farmers may not be able to allow themselves if participation is beneficial financially and not impacting the farm negatively otherwise.

On the other hand, six positive and eleven negative variables had to be added to the theoretical model deducted from the literature. Of course, it has to be kept in mind that during literature research only those variables were included which were mentioned by at least two studies. Therefore, it is possible that these variables do appear in some parts of Western Europe as well. However, they are clearly not common or of particular importance overall. Many of the added variables were also in Romania subordinate considerations mentioned by very few cases and not named by the experts. Therefore, these may be of neglectable relevance. However, one positive and several negative variables that had not been part of the theoretical model were found to be of major importance in the Târnava Mare area. Most notably, fear to be unable to comply had not been mentioned in the literature at all, but was one of the most important impediments in the Târnava Mare region, and the core cause in one of the pathways to dropping out. To some degree, this may be explained by cultural differences: farmer $L$ was afraid to be unable to comply because of vandalism, and claimed that this was a common problem. It could be hypothesised that this is related to a communist past which may have destroyed respect of other people's property, as well as solidarity. However, this needs to be tested by future research, along with the frequency of such cases. Furthermore, it cannot explain all manifestations of fear to be unable to comply, since other farmers who mentioned this variable referred to their own inability rather than vandalism. For these cases, it can only be speculated that the measures may be more difficult in Romania, the paperwork may be more complicated, farmers may be less informed, or face more uncertainties than in other parts of Europe. Clearly, more research would be useful to learn more about this.

Unreliability was a further common impediment which had not appeared in the literature. It could be suspected that this is simply because scheme administration is better in the OMS, and AESs in these countries are indeed more reliable. Romanian government institutions are known to be overworked and under-staffed (Popa, 2017), and most of the complaints by farmers were about unreliability related to the money not being paid on time. Therefore, it seems likely that this is indeed a problem which is more pronounced in Romania than in Western European countries.

Negative previous experiences also featured prominently as reasons against participation among the farmers of this study and even were the main impediment for one of the two nonparticipants, yet this variable did not appear in the literature either. Interestingly, its reverse did: a positive previous experience has been determined as an influential factor by several studies. Since it seems reasonable that all farmers are influenced by previous experiences, positive or negative, an explanation could be that the farmers in the existing studies mostly have not had any negative experiences with AESs or similar programs. Negative experiences of the farmers interviewed in the Târnava Mare region usually occurred because farmers had not understood the program well and therefore had to repay the money, or because the previous programs had been extremely unreliable. It seems plausible that farmers in the OMS may be better informed about program requirements and - as explained above - that government agencies may function better there. However, this, too, should be further solidified.

As for the positive variable, no trade-off featured prominently in farmers' decision-making in the Târnava Mare area, but had not been mentioned in the literature at all. This seems logical. As mentioned in the beginning, AESs in Romania are about maintaining existing traditional farm 
management rather than changing harmful practices. Thus, many Romanian farmers have to make very few changes on their farm to participate, and indeed have less to trade off when deciding whether to participate compared to the average Western European farmer. Furthermore, as was explained above, Romanian farmers may not tend to trade off extra income with luxury considerations such as whether participation means a loss of autonomy.

\section{Policy Recommendations}

Thus, it can be concluded that while Romanian farmers do share some considerations with those in the mostly Western European studies, there are also significant differences. Designing AESs solely based on the assertions of farmers in the OMS, as is currently the case, will therefore result in suboptimal uptake and discontent among farmers in Romania, and likely also among farmers in other NMS, where no research so far has been conducted. Therefore, the fact that results from research conducted in OMS are not sufficient to design policies for the whole EU should be acknowledged. Further research into the considerations and needs of farmers in NMS should be conducted, and CAP should then be redesigned accordingly to reflect these farmers' needs. Apart from this general recommendation to improve the AES's effectiveness across Europe, several more specific policy recommendations to improve the AES in the Târnava Mare region can be deducted from this paper's findings.

\section{More and better information}

First and foremost, providing more and better information is crucial to raise scheme uptake and to foster successful participation. Not only was lack of information about the requirements of AESs the most important impediment to (successful) participation, but it was also one of the main differences between participants in group 1 and those in group 2, who might thus run risk to drop out in the future. More information could also benefit some of those farmers who felt unable to comply, and it would definitely help to avoid negative experiences (which in turn led to dropping out and non-participation), since lack of information was one of the main causes of them.

\section{Simplify measures and bureaucracy}

Second, participation should be simplified, both in terms of measures and bureaucracy. Fear of inability to comply was one of the pathways to dropping out, and simplifying the program might thus allow to regain some of these farmers. Furthermore, bureaucracy was the second-most important impediment to participation and thus reducing it has the potential to gain a large number of additional participants. Also some of the farmers who named bad fit as an obstacle could be won as participants if measures were simplified and might thus fit their farm better. ADEPT's pilot program, which measures results instead of monitoring measures, demonstrates how this could be done. Indeed, all of the farmers who participated in ADEPT's program were very happy with it and several mentioned that they liked that it was unbureaucratic, thus underlining the importance of reducing bureaucracy in APIA's program. Finally, simplifying measures and bureaucracy would make the scheme easier to understand, reducing the need for information.

\section{More and better trained staff at APIA}

Third, there should be more and better trained staff at APIA. This would not only enable APIA to provide better information, but could also improve the reliability of schemes by delivering payments on time, thus again avoiding negative experiences. 


\section{More advisors}

Forth, and related to point three, there should be more advisors. This could be done by employing more staff at APIA, but also by providing funds for independent advisors, for example from NGOs. Trusted advisors played an important role especially in the decision of those farmers who were - at least initially - not motivated by environmental considerations, thus effectively creating new conservationists. Moreover, their assistance could also make up for lacking information to ensure successful participation.

\section{Raise payments}

Finally, raising the amount of money paid would clearly capture additional participants, since the money being too little was a common argument against participation. Furthermore, higher payments could also help to gain some farmers who would have to make more changes in their farming practices, and might even convince some of those who named bad fit as an impediment.

\section{POTENTIAL SHORTCOMINGS AND CONCLUSIONS}

As in any research project, there are certain limits to the findings of this paper. First of all, as has been mentioned before, the quantitative relevance of several variables remained unclear. Even for those variables whose importance was confirmed by the experts, though, it would be interesting to more accurately determine their frequency. Moreover, some of the causal relationships which have been found - such as that environmental reasons always led to successful participation - should also be solidified by future research. Since research was conducted only in the Târnava Mare area and also the experts interviewed were mostly focused on that region, more research is necessary to determine if the findings also hold for other parts of Romania and other AESs.

Another limit relates to the interviewees' honesty. In the analysis, interviewees were assumed to have expressed what they considered to be "true". Nevertheless, it is conceivable that interviewees may have wanted to place themselves in a better light. For example, $\mathrm{K}$ mentioned that some people cheated and consequently failed inspections. It is likely that if this had been the case for some of the interviewees they would not have admitted it, and for example rather have claimed to not have understood the requirements and to therefore have failed. Cheating as a reason for dropping out may thus have slipped this study, and instead may have been disguised as another variable, such as lack of information.

This point is closely related to another limit of this project, namely the problematic concept of "truth". The findings of this paper should not be mistaken for the "true" and only causes for why farmers do (not) participate in AEPs. Rather, they reflect farmers' reasoning; they are the results of the interviewees' attempts to produce a comprehensible explanation for their decisions (cf. Van Herzele et al., 2013, p. 113). Thus, to further solidify the findings of this paper, the effect that each of the variables found important here actually has on the final decision should be tested.

Furthermore, the fact that this paper's findings differ from the theoretical framework, which is a conglomerate of the findings in OMS, should not be over-interpreted. As the literature review has shown, there is also some variance between the results of Western European Studies. Thus, more research on Romania and other NMS is needed to eventually compare a meta-analysis of the OMS to a meta-analysis of the NMS. This paper, however, revealed that this venture will likely be 
fruitful. Furthermore, what is of significance already is the fact that several variables have been found to be of major importance in the Târnava Mare area which had not been mentioned by the existing literature at all. This is where the main difference between the Târnava Mare area and the OMS can be seen, and it constitutes the key finding of this paper.

Despite these limitations, two interesting conclusions can be drawn. First of all, the hypothesis posed in the beginning has been confirmed: There are significant differences in the factors influencing decision-making for or against AES participation between farmers in Romania and those of the mostly Western European countries examined so far. This proves that we cannot simply assume findings from the OMS to hold for the NMS, and highlights the importance of conducting research among farmers in NMS to design AESs according to their needs. Otherwise, schemes run the risk to underperform in these countries.

Secondly, however, there seem to be some considerations related to AES participation which are common to farmers across the European Union. In terms of agriculture, Romania is about as different as possible within the European Union from the Western European countries which have been the focus of existing research. Therefore, findings that were identical between Romania and the existing research are likely common to all European farmers.

Of course, much remains to be done. As indicated repeatedly throughout this paper, several of its findings should be further solidified by additional research. In particular, testing the quantitative relevance of the most important variables found in this project would be a fruitful next step. To formulate policy recommendations to improve AEPs across Romania, research outside the Târnava Mare region would be necessary. Also, as this paper has shown, further research into farmers' decision-making in other NMS will be beneficial to improve AESs there.

This paper has thus taken a first step towards a better understanding of farmers' decisionmaking for or against AES participation in the NMS. It provides future research with indications of where to continue, and, more importantly, proves that this research is much needed and fruitful. If others follow, findings can contribute to a significant improvement of AESs across the NMS, thus helping to safeguard one of the most valuable resources we have: the ecosystems that produce our food.

\section{REFERENCES}

BAYLIS, K., PEPLOW, S., RAUSSER, G., \& SIMON, L. (2008). Agri-environmental Policies in the EU and United States: A Comparison. Ecological Economics, 65, 753-764.

CLAASSEN, R., CATTANEO, A., \& JOHANSSON, R. (2008). Cost-effective Design of Agri-Environmental Payment Programs: U.S. Experience in Theory and Practice. Ecological Economics, 65, 737-752.

DEFRANCESCO, E., GATTO, P., RUNGE, F., \& TRESTINI, S. (2008). Factors Affecting Farmers' Participation in Agrienvironmental Measures: A Northern Italian Perspective. Journal of Agricultural Economics, 59(1), 114-131.

DISCOVER TÂRNAVA MARE - FUNDAȚIA ADEPT TANSILVANIA (2018). http://www.discovertarnavamare.org/discover/map/

DISCOVER TÂRNAVA MARE - FUNDAȚIA ADEPT TANSILVANIA (2018). http://www.discovertarnavamare.org/wpcontent/uploads/2011/12/tm-map1-med.jpg.

DOBRE, R. (2016). Banii pe agromediu: Ce sume plâtește APIA pentru 2015 și 2016 [Money for the Agro-Environment: How Much APIA Pays for 2015 and 2016]. Retrieved December 5 2017, from http://agrointel.ro/53027/baniipe-agromediu-ce-sume-plateste-apia-pentru-2015-si-2016/ 
DUCOS, G., DUPRAZ, P., \& BONNIEUX, F. (2009). Agri-environment Contract Adoption under Fixed and Variable Compliance Costs. Journal of Environmental Planning and Management, 52(5), 669-678.

ESPINOSA-GODED, M., BARREIRO-HURLÉ, J. \& RUTO, E. (2010). What Do Farmers Want from Agri-Environmental Scheme Design? A Choice Experiment Approach. Journal of Agricultural Economics, 61(2), 259-273.

EUROPEAN COMMISSION (2005). Agri-environment Measures: Overview on General Principles, Types of Measures, and Application. Retrieved December 7 2017, from https://ec.europa.eu/agriculture/sites/agriculture/ files/publi/reports/agrienv/rep_en.pdf

EUROPEAN COMMISSION (2017). Agri-environment Measures. Retrieved December 4 2017, from https://ec.europa.eu/agriculture/envir/measures_en

EUROSTAT (2012). Trend of EU expenditures on agri-environmental measures (million EUR), 1993-2010, EU-27. Retrieved December 2 2017, from http://ec.europa.eu/eurostat/statistics-explained/index.php/ File:Trend_of_EU_expenditures_on_agri-environmental_measures_(million_EUR),_1993-2010,_EU-27_.png

EUROSTAT (a). Agri-environmental indicator - consumption of pesticides. Retrieved December 4 2017, from http://ec.europa.eu/eurostat/statistics-explained/index.php/Agri-environmental_indicator__consumption_of_pesticides

EUROSTAT (b). Agricultural Census in Germany. Retrieved December 3 2017, from http://ec.europa.eu/eurostat/statistics-explained/index.php/Agricultural_census_in_Germany

EUROSTAT (c). Agricultural Census in Romania. Retrieved December 3 2017, from http://ec.europa.eu/eurostat/statistics-explained/index.php/Agricultural_census_in_Romania

EUROSTAT (d). Agricultural Census in the United Kingdom. Retrieved December 3 2017, from http://ec.europa.eu/eurostat/statistics-explained/index.php/Agricultural_census_in_the_United_Kingdom

FALCONER, K. (2000). Farm-level Constraints on Agri-Environmental Scheme Participation. A Transactional Perspective. Journal of Rural Studies, 16, 379-394.

FUNDAȚIA ADEPT (a). Agri-environment Schemes in Romania: A Success Story. Retrieved December 5 2017, from http://www.fundatia-adept.org/bin/file/BirdLifeBrussels.pdf

FUNDATTIA ADEPT (b). Conservation of the HNV Landscape: Landscape-scale Conservation of Târnava Mare through Natura 2000 and Agri-environment Measures. Retrieved December 8 2017, from http://www.fundatiaadept.org/?content=conservation

GLÄSER, J., \& LAUDEL, G. (2004). Experteninterviews und qualitative Inhaltsanalyse als Instrumente rekonstruierender Untersuchungen. Wiesbaden: VS Verl. für Sozialwissenschaften.

LASTRA-BRAVO, X.B., HUBBARD, C., GARROD, G., \& TOLÓN-BECERRA, A. (2015). What Drives Farmers' Participation in EU Agri-environmental Schemes? Results from a Qualitative Meta-analysis. Environmental Science and Policy, 54, 1-9.

MORRIS, C., \& POTTER, C. (1995). Recruiting the New Conservationists. Farmers' Adoption of Agri-environmental Schemes in the U.K. Journal of Rural Studies, 11(1), 51-63.

MORRIS, J., MILLS, J., \& CRAWFORD, I.M. (2000). Promoting Farmer Uptake of Agri-environment Schemes: The Countryside Stewardship Arable Options Scheme. Land Use Policy, 17, 241-254.

MORTIMER, S., MAUCHLINE, A., PARK, J., FINN, J., EDWARDS, D., \& MORRIS, J. (2010). Evaluation of Agri-Environment and Forestry Schemes with Multiple Objectives. EuroChoices, 9(1), 48-54.

PEERLINGS, J., \& POLMAN, N. (2004). Wildlife and Landscape Services Production in Dutch Dairy Farming: Jointness and Transaction Costs. European Review of Agricultural Economics, 31(4), 427-449.

POLMAN, N.B.P., \& SLANGEN, L.H.G. (2008). Institutional Design of Agri-environmental Contract in the European Union: The Role of Trust and Social Capital. NJAS - Wageningen Journal of Life Sciences, 55(4), 413-430.

POPA, R. (2017). Expert Interview with Razvan Popa, Fundația ADEPT, conducted by Meike Fienitz on April 24, 2017.

PRAGER, K., REED, M., \& SCOTT, A. (2012). Encouraging Collaboration for the Provision of Ecosystem Services at a Landscape Scale: Rethinking Agri-environmental Payments. Land Use Policy, 29, 244-249.

RUTO, E., \& GARROD, G. (2009). Investigating Farmers' Preferences for the Design of Agri-environment Schemes: A Choice Experiment Approach. Journal of Environmental Planning and Management, 52(5), 631-647. 
SATTLER, C., \& NAGEL, U.J. (2010). Factors Affecting Farmers' Acceptance of Conservation Measures: A Case Study from North-Eastern Germany. Land Use Policy, 27, 70-77.

SKERRATT, S. (1998). Socio-economic Evaluation of UK Agri-environmental Policy: Lessons from an ESA Case Study. Études et Recherches sur les Systèmes Agraires et le Développement, INRA Editions, 317-331.

VAN HERZELE, A., GOBIN, A., VAN GOSSUM, P., ACOSTA, L., WAAS, T., DENDONCKER, N., \& DE FRAHAN, B.H. (2013). Effort for Money? Farmers' Rationale for Participation in Agri-Environment Measures with Different Implementation Complexity. Journal of Environmental Management, 131, 110-120.

VANSLEMBROUCK, I., VAN HUYLENBROECK, G., \& VERBEKE, W. (2002). Determinants of the Willingness of Belgian Farmers to Participate in Agri-environmental Measures. Journal of Agricultural Economics, 53(3), 489-511.

WILSON, G.A. (1996). Farmer Environmental Attitudes and ESA Participation. Geoforum, 27(2), 115-131.

WILSON, G.A., \& HART, K. (2000). Financial Imperative or Conservation Concern? EU Farmers' Motivations for Participation in Voluntary Agri-environmental Schemes. Environment and Planning A, 32(12), 2161-2185.

WYNN, G., CRABTREE, B., \& POTTS, J. (2001). Modelling Farmer Entry into the Environmentally Sensitive Area Schemes in Scotland. Journal of Agricultural Economics, 52(1), 65-82.

WYNNE-JONES, S. (2013). Ecosystem Service Delivery in Wales: Evaluating Farmers' Engagement and Willingness to Participate. Journal of Environmental Policy and Planning, 15(4), 493-511. 